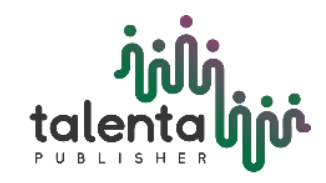

Jurnal Teknik Kimia USU

Vol. 08, No. 2, September 2019 | 85-89

ISSN : 2337-4888

Homepage: https://talenta.usu.ac.id/jtk

\title{
Ekstraksi Pektin dari Limbah Kulit Jeruk (Citrus sinensis) dengan Metode Ekstraksi Gelombang Ultrasonik Menggunakan Pelarut Asam Klorida (HCl)
}

\author{
Extraction of Pectin from Orange Peel Waste (Citrus sinensis) by Ultrasonic Method Using \\ Hydrochloric Acid (HCl) Solvent \\ Delvia Ariska Damanik*, Setiaty Pandia \\ Departemen Teknik Kimia, Fakultas Teknik, Universitas Sumatera Utara, \\ Jl. Almamater Kampus USU Medan 20155, Indonesia \\ *Email : delviaariska04@gmail.com
}

\begin{abstract}
Abstrak
Pektin merupakan polisakarida komplek yang mengandung asam galakturonat yang dihubungkan oleh $\alpha-(1-4)$ glikodidik yang terdapat di dalam dinding sel tanaman. Senyawa pectin banyak digunakan di industri farmasi, makanan dan minuman. Percobaan ini bertujuan untuk mengekstraksi pektin dari limbah kulit jeruk dengan metode ekstraksi gelombang ultrasonik dan mengetahui pengaruh konsentrasi dari pelarut yang digunakan serta kecepatan pengadukan pada karakterisasi pektin yang dihasilkan. Penelitian ini dilakukan dengan metode gelombang ultrasonik menggunakan pelarut asam kemudian ditambahkan etanol kedalam filtrate untuk mengendapkan pektin setelah itu dilakukan proses terakhir yaitu pengeringan untuk mendapatkan pectin kering. Variabel tetap yang digunakan dalam percobaan ini yaitu massa sampel 25 gram, pelarut asam klorida $(\mathrm{HCl})$, waktu ekstraksi 60 menit, suhu ekstraksi $60^{\circ} \mathrm{C}$, kecepatan gelombang ultrasonik $50 \mathrm{KHz}$ dan waktu pengendapan 16 jam. Sedangkan variable berubah yaitu konsentrasi pelarut yaitu0,025 N; 0,05 N; 0,075 N dan kecepatan pengadukan $0 \mathrm{rpm} ; 50 \mathrm{rpm} ; 100 \mathrm{rpm} ; 150 \mathrm{rpm}$. Hasil percobaan menunjukkan bahwa rendemen hasil ekstraksi terbaik diperoleh pada konsentrasi $0,075 \mathrm{~N}$ yaitu 20,12\%; kecepatan pengadukan $150 \mathrm{rpm}$ dengan kadar air 8,0 \%, kadar abu 4,0\%, dan kadar metoksil 7,44\%.
\end{abstract}

Kata Kunci: gelombang ultrasonik, pektin, kulit jeruk, kadar metoksil

\begin{abstract}
Pectin is complex polysaccharide contained D-galacturonic acid bonded by $\alpha-1,4$ glucosidic in plant cell walls. Pectin widely used in pharmaceutical, food and beverage industries. This study evaluates the effect of solvent and stirring speed on pectin characteristic. The study utilizes ultrasonic wave and acid solvent at the presence of ethanol to yield pectin following by drying to obtain dried pectin. This study carries out using 25 grams orange peels, $10 \%$, chloride acid solvent, 60 minutes extraction time, temperature of $60^{\circ} \mathrm{C}$, ultrasonic wave speed $50 \mathrm{KHz}$ and 16 hours settling time at various solvent concentrations $0.025 \mathrm{~N} ; 0.05 \mathrm{~N} ; 0.075 \mathrm{~N}$ and stirring speed $0 \mathrm{rpm} ; 50 \mathrm{rpm} ; 100 \mathrm{rpm} ; 150 \mathrm{rpm}$. The results showed that the highest yield of pectin extraction was obtained at concentration of $0.075 \mathrm{~N}$ with $20.12 \%$; stirring speed $150 \mathrm{rpm}$, water content $8.0 \%$; 4,0\% ash content, and $7.44 \%$ methoxyl content.
\end{abstract}

Keywords: ultrasonic wave, pectin, orange peels, methoxyl content

\section{Pendahuluan}

Jeruk (Citrus sinensis) merupakan salah satu komoditas pada buah-buahan yang mempunyai peranan sangat penting dipasaran baik di dalam negeri dan dunia, dalam bentuk segar atau olahan. Di Indonesia, produksi jeruk telah menduduki posisi kedua teratas setelah pisang. Komponen pada tanaman jeruk yang siap dipanen terdiri atas $65 \%$ buah yang dapat dimakan, $30 \%$ kulit; $5 \%$ biji [6].

Jumlah senyawa pektin yang berada di dalam kulit jeruk sebesar 29,84\%, sehingga kulit jeruk dapat digunakan sebagai bahan baku pembuatan pektin [11].

Kebutuhan pektin di Indonesia dari tahun ketahun mengalami peningkatan, pada tahun 2007 yaitu $183.050 \mathrm{~kg} /$ tahun s/d tahun 2013 yaitu 240.792 kg/tahun. Pada tahun 2020 diperkirakan kebutuhan pektin di Indonesia mencapai 1.320 ton/tahun, sehingga solusi untuk mengatasi kebutuhan pektin yang terus meningkat dengan memanfaatkan limbah kulit jeruk untuk diolah menjadi pektin dan dapat mengurangi pencemaran lingkungan [3]. 
Berdasarkan kondisi ini maka penelitian ini bertujuan untuk mengekstrak pektin dari limbah kulit jeruk dengan metode gelombang ultrasonik dan melihat pengaruh konsentrasi dari pelarut asam klorida yang digunakan.

\section{Teori}

Pektin merupakan produk karbohidrat yang dimurnikan dari ekstraksi asam pada kulit buah. Senyawa pectin merupakan polimer dari asam Dgalakturonat (turunan dari galaktosa) yang dihubungkan dengan ikatan beta-(1,4)-glukosida. Pada umumnya senyawa pektin diklasifikasikan menjadi tiga kelompok yaitu asam pektat, asam pektinat (pektin) dan protopektin. Protopektin banyak terdapat pada jaringan tanaman yang masih muda dan jumlahnya tergantung pada tingkat kematangan buah tersebut [12]. Pada Gambar 1 dapat dilihat struktur pektin yang ada pada tumbuhan.

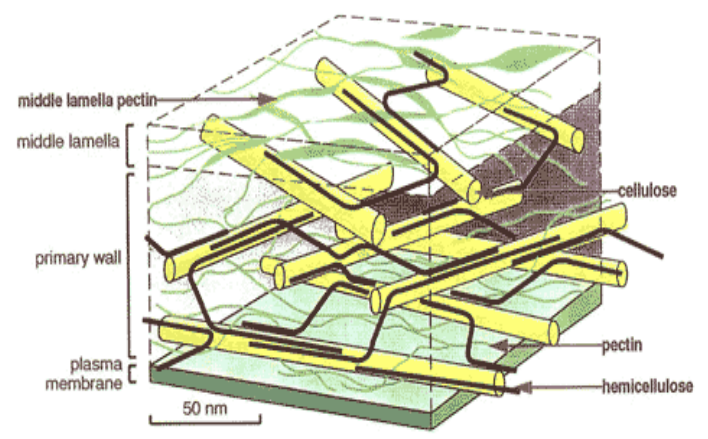

Gambar 1. Struktur Pektin pada Tumbuhan

Pektin merupakan komponen utama pada lamella tengah yang terdapat pada tanaman, pectin berperan sebagai perekat dan menjaga stabilitas jaringan dan sel. Pada tabel 1 dapat dilihat nilai dari kandungan pektin yang baik berdasarkan standar mutu International Pectin Producers Association (IPPA).

Tabel 1. Standar Mutu Pektin Berdasarkan Standar Mutu International Pectin Producers Association [5]

\begin{tabular}{|l|l|}
\hline \multicolumn{1}{|c|}{ Faktor Mutu } & \multicolumn{1}{c|}{ Kandungan } \\
\hline Kekuatan gel & Min 150 grade \\
Kandungan metoksil : & $>7,12 \%$ \\
- Pektin metoksil tinggi & $2,5-7,12 \%$ \\
- Pektin bermetoksil rendah & Min 35\% \\
Kadar asam galakturonat & Maks 12\% \\
Susut pengeringan (kadar air) & Maks 10\% \\
Kadar abu & Maks $12 \%$ \\
Kadar air & \\
Derajat esterifikasi untuk : & Min 50\% \\
- Pektin ester tinggi & Maks 50\% \\
- Pektin ester rendah & $0,15-0,45 \%$ \\
Bilangan Asetil & $600-800 \mathrm{mg}$ \\
Berat Ekivalen & \\
\hline
\end{tabular}

\section{Metodologi Penelitian}

Bahan baku yang digunakan pada percobaan ini adalah kulit buah jeruk dan bahan kimia berupa asam klorida $(\mathrm{HCl})$, air $\left(\mathrm{H}_{2} \mathrm{O}\right)$, etanol $\left(\mathrm{C}_{2} \mathrm{H}_{5} \mathrm{OH}\right)$, peraknitrat $\left(\mathrm{AgNO}_{3}\right)$, natrium hidroksida $(\mathrm{NaOH})$, natrium klorida $(\mathrm{NaCl})$, dan phenolptalein. Tahap awal adalah persiapan bahan baku dimana kulit buah jeruk dikeringkan untuk mengurangi kandungan air, kemudian sampel dihaluskan menggunakan belender untuk mendapatkan serbuk kulit jeruk agar mudah diestrak untuk menghasilkan filtrate yang maksimal.

Percobaan ini dilakukan dengan variasi konsentrasi yaitu $0,025 \mathrm{~N} ; 0,05 \mathrm{~N} ; 0,075 \mathrm{~N}$ dan kecepatan pengadukan $0 \mathrm{rpm} ; 50 \mathrm{rpm} ; 100 \mathrm{rpm}$; $150 \mathrm{rpm}$. Rangkaian alat yang digunakan pada percobaan ini dapat dilihat pada gambar 2 .

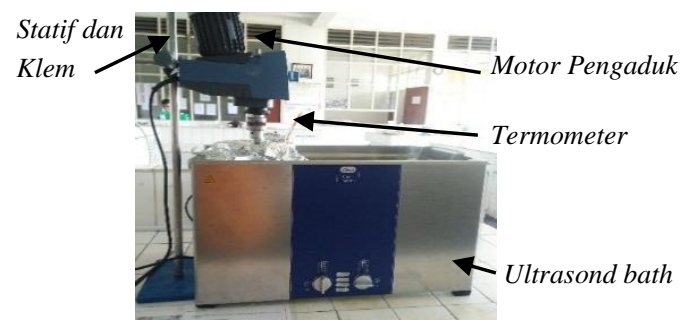

Gambar 2. Rangkaian Peralatan Ekstraksi

Air di tambahkan kedalam bahan baku sebanyak 30 kali dari banyaknya massa sampel yang digunakan dan diekstraksi didalam ultrason- bath dengan gelombang $50 \mathrm{KHz}$ dan pengadukan. Campuran yang telah diekstrak disaring dengan menggunakan kertas saring untuk memisahkan filtrate dari ampasnya. Setelah filtrate terpisah dilakukan pengendapan dengan menambahkan etanol, pengendapan dilakukan selama 16 jam. Endapan pektin yang diperoleh kemudian dikeringkan dalam oven pada temperatur $40^{\circ} \mathrm{C}$ selama 8 jam. Pektin kering yang dihasilkan kemudian dianalisa kadar air, kadar abu, berat ekivalen, kadar asam galakturonat dan kadar metoksilnya. Kemudian hasil analisa dibandingkan dengan standar mutu pektin berdasarkan standar mutu International Pectin Producers Association (IPPA).

\section{Hasil}

A. Pengaruh Konsentrasi Asam Klorida (HCl) Terhadap Perolehan Yield Pektin

Gambar 3 menunjukkan bahwa konsentrasi dan kecepatan pengadukan sangat berpengaruh terhadap rendemen pektin. Prinsip ekstraksi pektin adalah pengubahan protopektin yang tidak larut menjadi pektin yang dapat larut. Ekstraksi pektin ini dilakukan dengan cara hidrolisis asam maupun secara enzimatis.

Penggunaan asam klorida $(\mathrm{HCl})$ sebagai pelarut dilakukan karena memiliki daya ekstrak yang tinggi dan ikatan valensi 1, sehingga tingkat keasaman 
yang tidak terlalu tinggi. Tingkat keasaman yang tinggi tidak baik pada proses ekstraksi pektin, karena akan menyababkan terdegradasinya pektin menjadi asam pektat dan membuat yield pektin yang semakin sedikit [10].

Jumlah pelarut yang digunakan untuk mengekstraksi juga sangat berpengaruh terhadap hasil yield pektin. Semakin banyak pelarut yang digunakan pada saat ekstraksi maka pektin yang terekstrak juga akan semakin banyak, karena pelarut dapat melarutkan hamper semua pektin yang terkandung di dalam kulit jeruk. Jumlah pelarut yang sedikit tidak dapat mengekstrak pectin secara optimal. Ekstraksi dilakukan selama pelarut yang digunakan belum jenuh. Pelarut yang telah jenuh tidak dapat mengekstraksi lagi dan kurang baik untuk melakukan ekstraksi karena gaya pendorong (driving force) semakin lama semakin kecil [7].

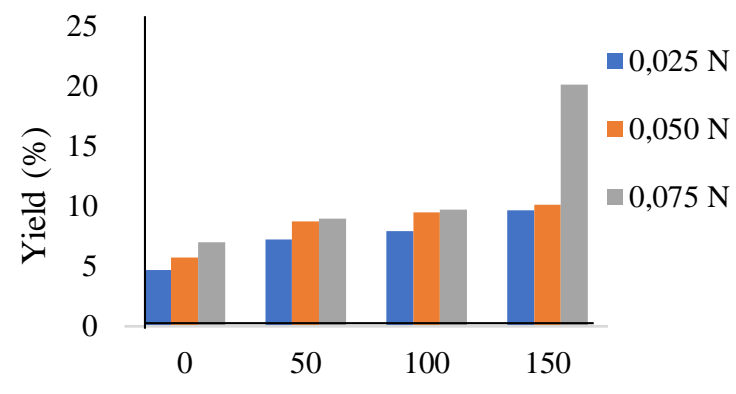

Kecepatan Pengadukan (rpm)

Gambar 3. Pengaruh Konsentrasi Asam Klorida (HCl) Terhadap Rendemen Pektin

\section{B. Pengaruh Konsentrasi Asam Klorida (HCl) Terhadap Kadar Air Pektin}

Kadar air bahan berpengaruh terhadap masa simpan. Kadar air yang tinggi menyebabkan kerentanan terhadap aktivitas mikroba. Dalam upaya memperpanjang masa simpan pektin, dilakukan pengeringan pada oven suhu $40{ }^{\circ} \mathrm{C}$ selama 8 jam. Pengeringan pada suhu rendah bertujuan meminimalkan degradasi pektin.

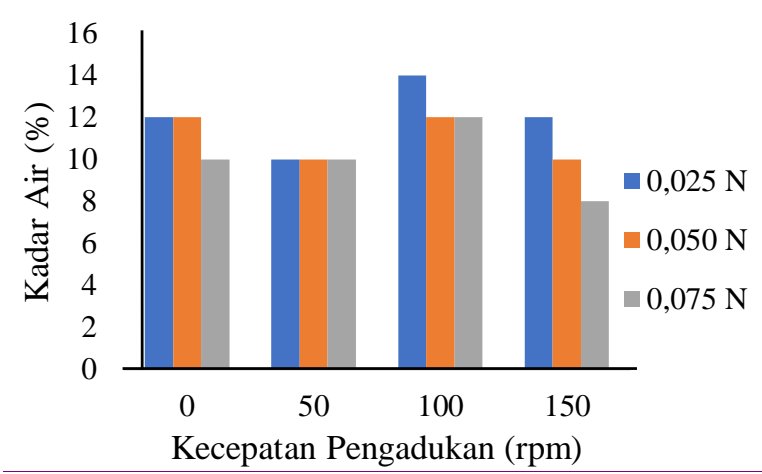

Gambar 4. Pengaruh KonsentrasiAsamKlorida (HCl) Kadar Air Pektin

Kadar air pektin yang dihasilkan berkisar antara 8-12\%. Batas maksimum nilai kadar air yang diizinkan yaitu $12 \%$ [4]. Berdasarkan standar IPPA
(International Pectin Producers Association), semua perlakuan masih memenuhi standar apabila kadar air pektin di bawah $12 \%$. Kadar air yang dihasilkan dapat dipengaruhi oleh rendemen dari pektin. Semakin tinggi rendemen pektin, kadar air yang dihasilkan semakin tinggi [1]. Untuk melihat kadar air yang dihasilkan pada percobaan ini dapat dilihat pada gambar 4 .

\section{Pengaruh Konsentrasi Asam Klorida ( $\mathrm{HCl}$ ) Terhadap Kadar Abu Pektin}

Kadar abu menunjukan bahwa masih ada komponen anorganik yang tertinggal didalam pektin. Semakin kecil kadar abu maka kemurnian pectin akan semakin baik. Pektin dengan mutu terbaik memiliki kadar abu 0\% [5]. Perlakuan yang dilakukan dengan menggunakan asam dapat mengakibatkan terhidrolisis pectin dari ikatan kalsium dan magnesium. Peningkatan reaksi hidrolisis pada proto pectin mengakibatkan bertambah komponen $\mathrm{Ca}^{2+}$ dan $\mathrm{Mg}^{2+}$ di dalam larutan pengesktrak [9]. Hasil penelitian menunjukkan kadar abu pektin yang diperoleh berkisar antara 3\%-10\% yang sesuai dengan standar mutu kadar abu pektin yang ditetapkan IPPA (International Pectin Producers Association), yaitu maksimum $10 \%$. Untuk melihat kadar abu yang dihasilkan pada percobaan ini dapat dilihat pada gambar 5 .

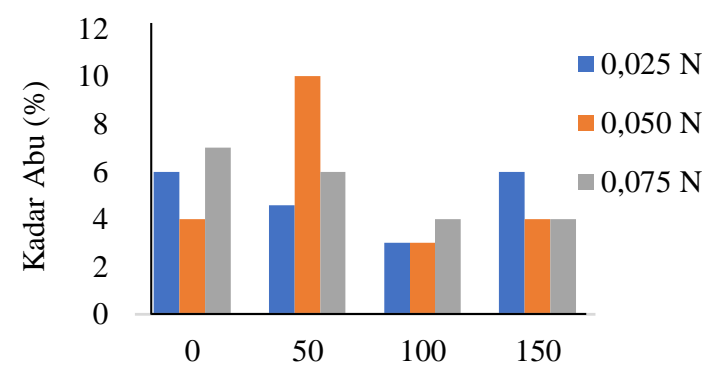

Kecepatan Pengadukan (rpm)

Gambar 5. Pengaruh Konsentrasi Asam Klorida (HCl) terhadap kadar abu pektin

\section{Pengaruh Konsentrasi Asam Klorida Terhadap Berat Ekivalen Pektin}

Berat ekivalen digunakan untuk menghitung kandungan dari asam anhydrouronic dan tingkat esterifikasi. Ditentukan dengan titrasi dengan natrium hidroksida dengan $\mathrm{pH} 7,5$ baik indikator merah atau hitam [8].

Pada gambar 6 dapat dilihat adanya penurunan pada berat ekivalen, semakin tinggi kecepatan pengadukan dengan konsentrasi yang tinggi juga menghasilkan berat ekivalen yang semakin rendah. Pada percobaan ini berat ekivalen yang diperoleh dapat diterima, karena berdasarkan standar IPPA (International Pectin Producers Association) berat ekivalen adalah 600-800 mg. 


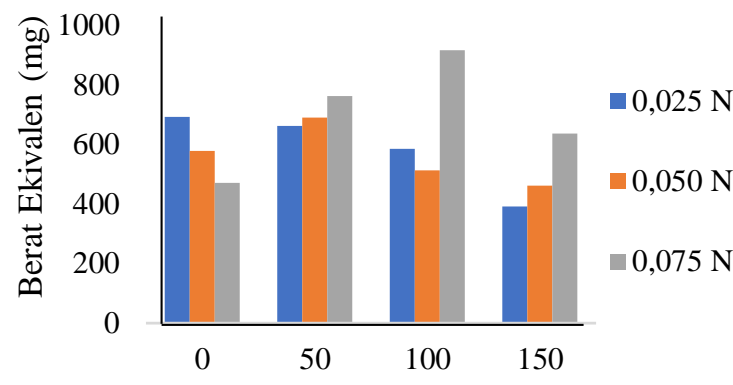

Kecepatan Pengadukan (rpm)

Gambar 6. Pengaruh Konsentrasi Asam Klorida (HCl) terhadap berat ekivalen pektin

\section{E. Pengaruh Konsentrasi Asam Klorida (HCl) Terhadap Kadar Metoksil Pektin}

Kadar metoksil dapat didefinisikan sebagai jumlah mol pada etanol yang terdapat didalam 100 mol asam galakturonat. Dimana kadar metoksil memiliki peranan yang sangat penting dalam menentukan sifat-sifat fungsional larutan pektin dan dapat mempengaruhi struktur dan tekstur dari gel pektin.

Kadar metoksil pectin hasil ekstraksi berkisar antara 3,72-10,54\%. Menurut [9] Pektin dapat dikatakan bermetoksil tinggi apabila memiliki nilai kadar metoksil sama dengan atau lebih dari 7\%, apabila kadar metoksil dibawah $7 \%$ maka dapat dikatakan pectin tersebut bermetoksil rendah. Hal ini dikarenakan kadar asam galakturonat yang terdapat dalam kulit jeruk manis banyak. Semakin banyak kadar asam galakturonat yang termetoksil maka kadar metoksilnya semakin tinggi [7]. Untuk melihat kadar metoksil yang dihasilkan pada percobaan ini dapat dilihat pada gambar 7 .

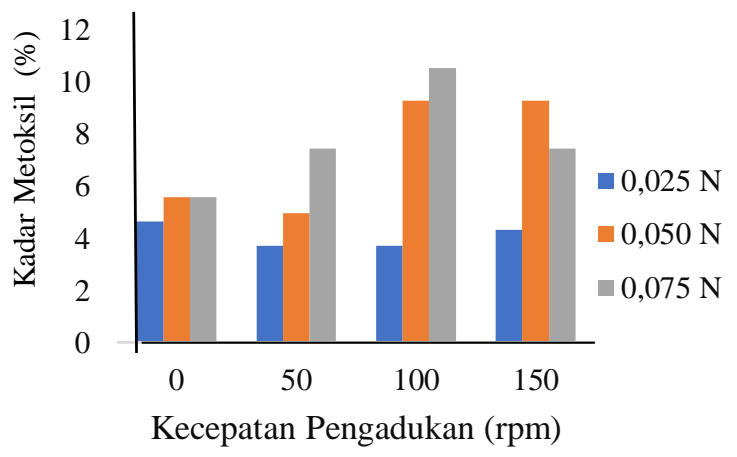

Gambar 7. Pengaruh Konsentrasi Asam Klorida (HCl) terhadap kadar metoksil pektin

\section{Kesimpulan}

Kesimpulan yang dapat diambil pada percobaan yang telah dilakukan yaitu :

1. Rendemen yang terbaik pada konsentrasi 0,075 $\mathrm{N}$ dan kecepatan pengadukan $150 \mathrm{rpm}$ yaitu $20,12 \%$.

2. Kadar air yang tertinggi diperoleh sebesar $14 \%$ pada Konsentrasi $0,025 \mathrm{~N}$ dan kecepatan pengadukan $100 \mathrm{rpm}$.
3. Kadar abu yang terbaik diperoleh sebesar $3 \%$ pada konsentrasi $0,025 \mathrm{~N}$ dan $0,050 \mathrm{~N}$ dengan kecepatan pengadukan $100 \mathrm{rpm}$.

4. Kadar metoksil tertinggi diperoleh sebesar $10,54 \%$ pada konsentrasi $0,075 \mathrm{~N}$ dan kecepatan pengadukan $100 \mathrm{rpm}$.

5. Kualitas pektin yang dihasilkan dengan pelarut asam klorida $(\mathrm{HCl})$ ini telah memenuhi kriteria yang telah ditetapkan oleh IPPA (International Pectin Producers Association).

\section{Daftar Pustaka}

[1] D. I. P. Lumbantoruan, S. Ginting, I. Suhaidi, Pengaruh Konsentrasi Bahan Pengendap Dan Lama Pengendapan Terhadap Mutu Pektin Hail Ekstraksi Dari Kulit Durian, Jurnal Rekayasa Pangan Dan Pertanian, 2(2) (2014) 58-63.

[2] D. J. Mcclements, Advances in The Application of Ultrasound in Food Analysis And Rocessing. Trends Food Sci. Techn. 6(9) (1995) 293-299.

[3] H.A.Cahyanto, Pektin Jeruk Bali (Citrus Maxima, L) Dalam Formulasi Sirup Kering Buah Mengkudu. Jurnal Riset Teknologi Industri, 1(1) (2017) 43-48.

[4] International Pectin Producer Association. Who Is Pectin? Http://Www. Ippa.Info/Index. Htm 2003, Diakses pada November (2018).

[5] K. A. T. Castillo-Israel, S. F. Baguio, M. D. B. Diasanta, R. C. M. Lizardo, E. I. Dizon, and M. I. F. Mejico, Extraction and Characterization of Pectin From Saba Banana Peels Wastes: A Preliminary Study. International Food Research Journal 22(1) (2015) 202-207.

[6] N. Solika, M. Napitupulu, dan S. T. Gonggo. Bioadsorpsi $\mathrm{Pb}$ (II) Menggunakan Kulit Jeruk Siam(Citrus Reticulata), Jurnal Akademika, Kim, 6(3) (2017) 160-164.

[7] P. Irene, Satiruiani, F. E. Soetaredjo, H. Hindarso, Ekstraksi Pektin Dari Berbagai Macam Kulit Jeruk. Widya Teknik, 6(1) (2017) $1-10$.

[8] R. N. Shukla, K. L. Bala, A. Kumar, A. A. Mishra. K. C. Yadav. W. Elizabeth Devi, extraction of pectin from citrus fruit peel and itsutilization in preparation of jelly. International Journal of Engineering Research \& Technology (IJERT), 3(5) (2014) 22780181.

[9] S. Maulana, Ekstraksi dan Karakterisasi Pektin Dari Limbah Kulit Pisang Uli (Musa Paradisiaca), Uin Syarif Hidayatullah Jakarta, (2015) 42-45.

[10] Tuhuloula, A. L. Budiyarti, E. N. Fitriana, Karakterisasi Pektin Dengan Memanfaatkan Limbah Kulit Pisang Menggunakan Metode Ekstraksi, Konversi, 2(1) (2013) 21-26.

[11] V. Batori, M. Jabbari, Akesson, P. R. Lennartson, M. J. Taherzadeh, A. Zamani, 
Production of Pectin Cellulose Waste Bio films, International Journal of Polymer Science, 9(4) (2017) 1-8.
[12] V. Fitria, Karakteristik Pekin Hasil Ekstraksi Dari LimbahKulit Pisang Kepok, Skripsi, Universitas Islam Negeri Syarif Hidayatullah, Jakarta,(2015)38-46. 